\title{
SP3 wt Allele
}

National Cancer Institute

\section{Source}

National Cancer Institute. SP3 wt Allele. NCI Thesaurus. Code C98043.

Human SP3 wild-type allele is located in the vicinity of $2 \mathrm{q} 31$ and is approximately $59 \mathrm{~kb}$ in length. This allele, which encodes transcription factor Sp3 protein, is involved in both transcriptional regulation and DNA binding. 